\title{
Dipeptidyl Peptidase 4 Distribution in the Human Respiratory Tract
}

\section{Implications for the Middle East Respiratory Syndrome}

\author{
David K. Meyerholz, ${ }^{*}$ Allyn M. Lambertz, ${ }^{*}$ and Paul B. McCray, Jr.
}

From the Departments of Pathology* and Pediatrics, ${ }^{\dagger}$ Carver College of Medicine, University of Iowa, Iowa City, Iowa

\author{
Accepted for publication \\ September 4, 2015. \\ Address correspondence to Paul \\ B. McCray, Jr., M.D., 6320 \\ PBDB, Department of Pediat- \\ rics, Carver College of Medi- \\ cine, University of Iowa, Iowa \\ City, IA 52242. E-mail: paul- \\ mccray@uiowa.edu.
}

\begin{abstract}
Dipeptidyl peptidase 4 (DPP4, CD26), a type II transmembrane ectopeptidase, is the receptor for the Middle Eastern respiratory syndrome coronavirus (MERS-CoV). MERS emerged in 2012 and has a high mortality associated with severe lung disease. A lack of autopsy studies from MERS fatalities has hindered understanding of MERS-CoV pathogenesis. We investigated the spatial and cellular localization of DPP4 to evaluate an association MERS clinical disease. DPP4 was rarely detected in the surface epithelium from nasal cavity to conducting airways with a slightly increased incidence in distal airways. DPP4 was also found in a subset of mononuclear leukocytes and in serous cells of submucosal glands. In the parenchyma, DPP4 was found principally in type I and II cells and alveolar macrophages and was also detected in vascular endothelium (eg, lymphatics) and pleural mesothelia. Patients with chronic lung disease, such as chronic obstructive pulmonary disease and cystic fibrosis, exhibited increased DPP4 immunostaining in alveolar epithelia (type I and II cells) and alveolar macrophages with similar trends in reactive mesothelia. This finding suggests that preexisting pulmonary disease could increase MERS-CoV receptor abundance and predispose individuals to MERS morbidity and mortality, which is consistent with current clinical observations. We speculate that the preferential spatial localization of DPP4 in alveolar regions may explain why MERS is characterized by lower respiratory tract disease. (Am J Pathol 2016, 186: 78-86; http://dx.doi.org/10.1016/j.ajpath.2015.09.014)
\end{abstract}

Middle East respiratory syndrome (MERS) was recognized as a significant illness on the Saudi Arabian peninsula in mid-2012, and the causative agent was rapidly identified as a novel coronavirus (CoV)-MERS-CoV. ${ }^{1}$ Since its emergence, the World Health Organization has been notified of 1542 laboratory-confirmed cases of MERS-CoV infection in $>2$ dozen countries, resulting in at least 544 related deaths (http://www.who.int/emergencies/mers-cov/en; last accessed September 12, 2015). Available data indicate that men are more commonly infected than women, with a median age of 47 years. $^{2-4}$ Although human-to-human or zoonotic spread of MERS has not reached epidemic or pandemic levels, its potential to spread among individuals was found in health care settings in the Middle East ${ }^{5}$ and by the recent outbreak in South Korea caused by a single infected individual. ${ }^{6}$

Most fatal MERS cases have occurred in individuals 60 years or older, frequently associated with significant comorbidities, such as obesity, renal or cardiac disease, diabetes, lung disease, or immunocompromise. ${ }^{7}$ Severely affected individuals have manifested significant respiratory symptoms, including cough, fever, dyspnea, and chest pain. ${ }^{2-4}$ Many seriously ill patients have progressed to respiratory failure and required ventilatory support. These patients exhibited dense airspace and interstitial lesions on chest radiography and computed tomography. ${ }^{1,3,8}$ In addition to the pulmonary manifestations, other reported problems in seriously ill patients include hyperkalemia, disseminated intravascular coagulopathy, pericardial effusion, central nervous system manifestations, ${ }^{9}$ and multiorgan

Supported by NIH grants PO1 AI-060699, P01 HL-51670, and P01 HL091842 (P.B.M.), and P30 DK054759 (D.K.M.), the Comparative Pathology Laboratory, the Roy J. Carver Charitable Trust, and the Cystic Fibrosis Foundation.

Disclosures: None declared. 
Table 1 Comparison of Cellular Dipeptidyl Peptidase 4 Immunostaining Scores between Large and Small Conducting Airways

\begin{tabular}{llll}
\hline Airway & $\begin{array}{l}\text { Ciliated } \\
\text { cells }\end{array}$ & $\begin{array}{l}\text { Nonciliated } \\
\text { cells }\end{array}$ & Goblet cells \\
\hline Large airway & $1.1 \pm 0.3$ & $1.1 \pm 0.3$ & $2.1 \pm 0.7$ \\
Small airway & $1.5 \pm 0.7$ & $1.5 \pm 0.6$ & $1.8 \pm 0.7$ \\
$P$ value* & 0.23 & 0.17 & 0.43 \\
\hline
\end{tabular}

*Mann-Whitney U-test.

failure. $^{2-4}$ To date, a lack of autopsy pathology data from patients who have died of MERS has hindered understanding of disease pathogenesis.

Epidemiologic studies have established that MERS is zoonotic in origin, with evidence of a closely related virus in dromedary camels on the Arabian peninsula and throughout Africa. ${ }^{10-12}$ Spread from camels to humans is documented, ${ }^{13}$ as well as person-to-person spread among health care workers in hospital settings. ${ }^{5}$ Unlike the 'super spreader' cases described with SARS-CoV, ${ }^{14,15}$ the spread of MERS-CoV from person-to-person is inefficient, but this could change with virus evolution. ${ }^{16,17}$ MERS-CoV has also been detected in individuals with mild, influenza-like illnesses, those with a dengue-like illness, and those without obvious disease signs or symptoms, ${ }^{18-21}$ suggesting that there may be a larger disease burden than currently recognized.

Shortly after MERS-CoV was discovered, its cellular receptor, dipeptidyl peptidase 4 (DPP4, CD26), was identified. ${ }^{22}$ The structural residues comprising the receptor-binding domain have been defined by co-crystallization of the MERS-CoV spike glycoprotein and DPP4. ${ }^{23}$ DPP4 is a single-pass type II transmembrane glycoprotein with a short N-terminal cytoplasmic tail. The native protein is a homodimer. DPP4 cleaves $\mathrm{X}$-proline dipeptides from $\mathrm{N}$-terminus of polypeptides and in doing so may functionally modify many substrates, including growth factors, neuropeptides, cytokines, chemokines, and vasoactive peptides. $^{24}$

DPP4 is expressed in many tissues and cell types, including kidney, intestine, liver, thymocytes, and several cells of hematopoietic lineage. ${ }^{24}$ DPP4 expression is increased on activation of T, B, and natural killer cells and is considered a marker of functional activation. ${ }^{24}$ DPP4 is also shed from the surface of many cell types and is present in soluble forms in plasma. ${ }^{25}$ Although there are limited reports describing aspects of DPP4 expression in animal and human tissues and cell types, ${ }^{25-27}$ there has been no comprehensive survey of its cellular expression in the human respiratory tract. We localize DPP4 expression in normal and diseased human respiratory tissues to identify the pulmonary cell types that may be susceptible to MERS-CoV infection and thereby obtain insight into MERS pathogenesis.

\section{Materials and Methods}

\section{Tissues}

This study was approved by the institutional review board of the University of Iowa. Formalin-fixed, paraffin-embedded (FFPE) lung tissues were collected from archival tissues from autopsy tissues or lung donors, whereas archival nasal tissues $(n=3)$ were collected from biopsy samples. Portions of the cases also had trachea or primary bronchi (large airways) available for examination. These were scored for DPP4 immunostaining and compared to small airways defined by intrapulmonary bronchi and bronchioles (Table 1). We gathered sufficient lung samples to compare 2 clinical groups (Table 2). Group 1 was composed of 16 healthy lung tissues (defined as lacking clinical evidence of active or chronic lung disease), whereas group 2 was composed of chronic lung disease tissues defined by chronic obstructive pulmonary disease (COPD, $n=4$ ) or cystic fibrosis $(\mathrm{CF}, n=8)$ clinical diagnoses. The use of a control population (group 1), even though healthy and often younger, allows several advantages. It provides a control group for comparison to the diseased individuals (group 2). Furthermore, our total pool of cases ranged from 2 months to 76 years of age, allowing evaluation of age-related changes in DPP4 expression (Table 3).

\section{Immunohistochemistry}

DPP4 expression was detected using immunohistochemistry (IHC) on paraffin-embedded tissues. Briefly, tissues were sectioned (approximately $4 \mu \mathrm{m}$ ) and hydrated through a series of graded alcohol and xylene baths, and antigen

Table 2 Scoring of Cellular Dipeptidyl Peptidase 4 Immunostaining in Lung Cell Types

\begin{tabular}{|c|c|c|c|c|}
\hline Cell & Unaffected & COPD & CF & $P$ value* \\
\hline Ciliated cells & $1.6 \pm 0.2(n=16)$ & $1.5 \pm 0.3(n=4)$ & $1.4 \pm 0.2(n=8)$ & 0.74 \\
\hline Nonciliated & $1.4 \pm 0.2(n=16)$ & $2.5 \pm 0.3(n=4)$ & $1.3 \pm 0.2(n=8)$ & 0.53 \\
\hline Type II cells & $4.1 \pm 0.2(n=16)$ & $5.0 \pm 0.0(n=4)$ & $4.5 \pm 0.2(n=8)$ & 0.014 \\
\hline Type I cells & $1.8 \pm 0.2(n=16)$ & $2.5 \pm 0.3(n=4)$ & $2.6 \pm 0.2(n=8)$ & 0.012 \\
\hline Alveolar macrophages & $4.2 \pm 0.2(n=16)$ & $4.8 \pm 0.3(n=4)$ & $4.8 \pm 0.2(n=8)$ & 0.03 \\
\hline
\end{tabular}

*Mann-Whitney $U$-test comparing group 1 (unaffected) and group 2 (COPD and CF). Bold text indicates $P<0.05$.

CF, cystic fibrosis; COPD, chronic obstructive pulmonary disease; SMG, submucosal gland. 
Table 3 Correlation of Patient Age and Dipeptidyl Peptidase 4 Immunostaining Scores for Type I and Type II Cells in Lung

\begin{tabular}{lcl}
\hline Group & $R$ value & $P$ value \\
\hline Type I cells in group 1 & 0.1915 & 0.4728 \\
Type I cells in groups 1 and 2 & 0.1787 & 0.3629 \\
Type II cells in group 1 & -0.4887 & $\mathbf{0 . 0 0 0 1}$ \\
Type II cells in groups 1 and 2 & 0.1089 & 0.5813 \\
\hline
\end{tabular}

Bold text represents $P<0.05$.

retrieval was performed (Decloaking Chamber NxGen; Biocare Medical, Concord, CA) in citrate buffer ( $\mathrm{pH}$ 6.0, $110^{\circ} \mathrm{C}$ for 15 minutes). Endogenous peroxidase was quenched with $3 \%$ hydrogen peroxide (8 minutes) and nonspecific background blocked with $1 \%$ horse serum (30 minutes). DPP4 was detected using a mouse monoclonal antiDPP4 antibody (1:200, clone 11D7, TA500733; Origene Technologies Inc, Rockville, MD) and secondary kit (Mouseon-Farma; Biocare Medical). Antibodies were visualized with chromogen (DAB Plus and DAB Enhancer; Dako, Carpinteria, CA). Slides were dehydrated through a series of alcohol and xylene baths and routinely coverslipped.

DPP4 immunostaining was optimized and validated on FFPE primary airway cell cultures either expressing DPP4 or lacking its expression. An additional validation step was performed on human kidney where renal tubules are known to have robust immunostaining. These steps have been useful to enhance specific staining while greatly minimizing nonspecific staining that can confound localization studies in tissues. Furthermore, optimization and validation studies were performed on FFPE tissues similar to the test samples to enhance consistency.

\section{Morphometry}

Tissues were evaluated and scored by a pathologist using a postexamination masking technique. ${ }^{28}$ DPP4 expression in the lung was assessed by scoring of the cellular distribution of immunostaining according to morphologic cell type using the following grades: 1 , absent; 2 , rare $(<1 \%) ; 3$, low numbers ( $2 \%$ to $33 \%)$; 4 , moderate numbers $(34 \%$ to $66 \%$ ); and 5 , common (67\% to $100 \%)$.

For evaluation of DPP4 expression changes within lungs, areas with and without disease (eg, hyperplasia, inflammation, remodeling) were selected from cases of CF. Alveolar macrophages were selected for this study because they are easily identified as single cells within the alveolar lumen, whereas other cell types are more difficult to definitively discern in the absence of staining, which could skew results. Alveolar macrophages ( $>30$ per sample area) were counted and scored for DPP4 staining using the following grades: 1, no staining; 2, weak, perceptible staining; 3 , moderate, diffuse cytoplasmic staining; and 4, robust, dark staining. Scores were averaged, and areas with and without disease were then compared using the paired $t$-test.

\section{Statistical Analysis}

Unless otherwise specified, comparison of morphometric scoring data between groups was performed with MannWhitney test, and statistical significance was set at $P<0.05$.

\section{Results}

We determined the cellular expression of DPP4 protein in the human respiratory tract from nasal cavity to airways to lung.

\section{Nasal Mucosa}

The surface epithelium of the nasal mucosa lacked DPP4 immunostaining (Figure 1A). In contrast, DPP4 immunostaining was seen in scattered mononuclear lymphoid cells and the apical surface of serous cells of the submucosal gland cells (Figure 1, A and B).

\section{Airways}

In the surface epithelium, DPP4 immunostaining was detected in uncommon foci as solitary to scattered goblet cells, nonciliated cells, and/or ciliated cells (Figure 2A). DPP4 was also detected in scattered mononuclear round cells within the epithelium and in the subepithelial tissues (Figure 2, A and C-E). Robust apical to cytoplasmic DPP4 immunostaining was present in the submucosal gland serous cells and rare duct epithelial cells but was lacking in mucous cells (Figure 2, B and C). Sometimes, the DPP4 signal appeared to be filling luminal spaces (Figure 2B) possibly

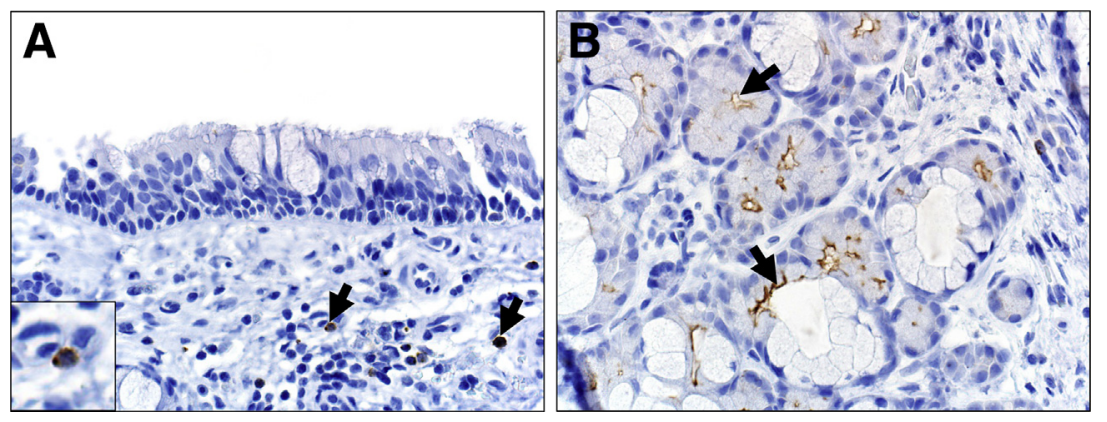

Figure 1 Dipeptidyl peptidase 4 (DPP4) immunostaining in nasal mucosa. A: Surface epithelial cells lack DPP4 immunostaining but scattered mononuclear cells in the subepithelial connective tissue have cytoplasmic staining (arrows). B: In contrast, the apical surface of serous cells (arrows) in submucosal glands commonly have robust DPP4 immunostaining. Original magnification, $\times 400$ (A and B). 


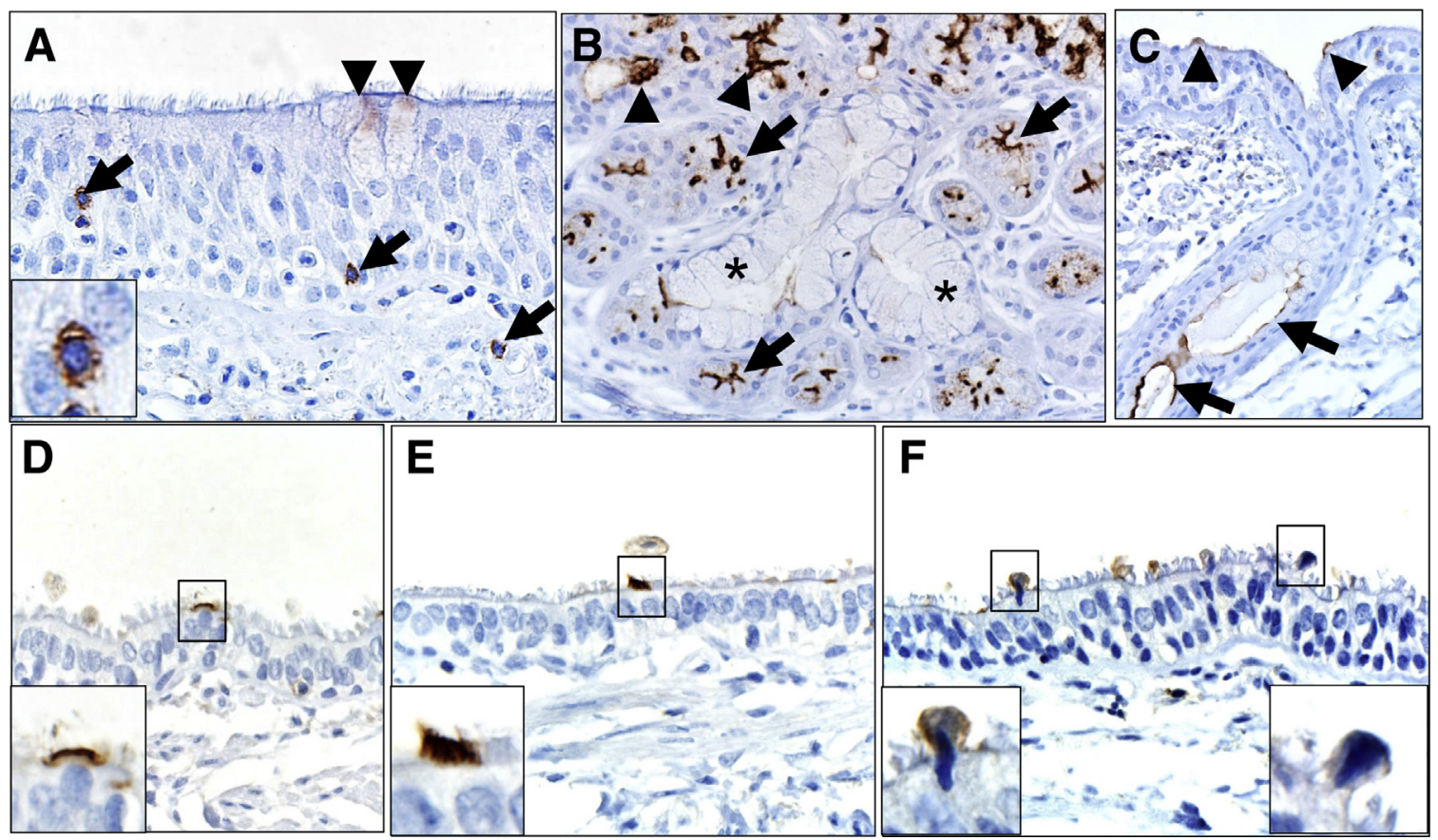

Figure 2 Dipeptidyl peptidase 4 (DPP4) immunostaining in airways. A: In the trachea, DPP4 is observed in scattered mononuclear cells (arrows and inset) within the epithelium and in the subepithelial connective tissue, and DPP4 is sometimes seen in the apical cytoplasm of goblet cells (arrowheads). B: Submucosal glands have apical to cytoplasmic immunostaining in serous cells (arrows), but mucous cells (asterisks) lack immunostaining. Gland lumens also stain positive (arrowheads). C: In bronchus, apical staining is seen in scattered to solitary nonciliated cells (arrowheads), and apical immunostaining is seen in uncommon submucosal gland ducts (arrows). D and E: Bronchioles have robust solitary apical immunostaining in scattered to solitary nonciliated cells (D, inset) or less commonly apical border of ciliated cells including cilia (E, inset). F: Cytoplasmic staining is also uncommonly seen in select nonciliated cells that appear to be undergoing extrusion from the epithelial surface (F, insets). Original magnification: $\times 600(\mathbf{A}$ and $\mathbf{D}-\mathbf{F}) ; \times 2100(\mathbf{A}$, inset); $\times 400(\mathbf{B}) ; \times 200(\mathbf{C}) ; \times 100(\mathbf{D}-\mathbf{F}) ; \times 225(\mathbf{D}-\mathbf{F}$, insets).

representing soluble DPP4 released by serous cells, ductal epithelia, or a combination thereof. We also occasionally observed cytoplasmic staining in nonciliated cells that appeared to be undergoing morphologic degeneration and extrusion from the surface epithelium (Figure 2F).

Although cell staining was uncommon in conducting airways, smaller airways appeared to have more frequent DPP4 detection in the surface epithelia. To test this, we examined immunostaining scores for large airways compared with small airways. Smaller airways had nonsignificant trends toward increased incidence of DPP4 immunostaining in ciliated and nonciliated cells (Table 1). This observation may also be influenced by the larger sampling area represented of smaller airways compared with larger airways in microscopic lung sections.

\section{Lung Parenchyma and Other Regions}

DPP4 immunostaining was detected in alveolar type II cells, type I cells, and alveolar macrophages (Figure 3A). The endothelium of pulmonary vessels had multifocal DPP4 immunostaining (Figure 3B). Thin walled vessels devoid of erythrocytes (indicative of lymphatics) (Figure 3B) often had stronger staining than those with erythrocytes (indicative of venules). The general gradient of staining intensity observed was lymphatics greater than venules greater than arterioles. Some capillaries occasionally had staining. Of interest, intravascular valves (when present) (Figure 3C) exhibited preferential strong staining in lymphatics and veins. Pulmonary lymph nodes also had abundant DPP4 immunostaining in lymphatic vessels of the medullary sinuses (Figure 3D).

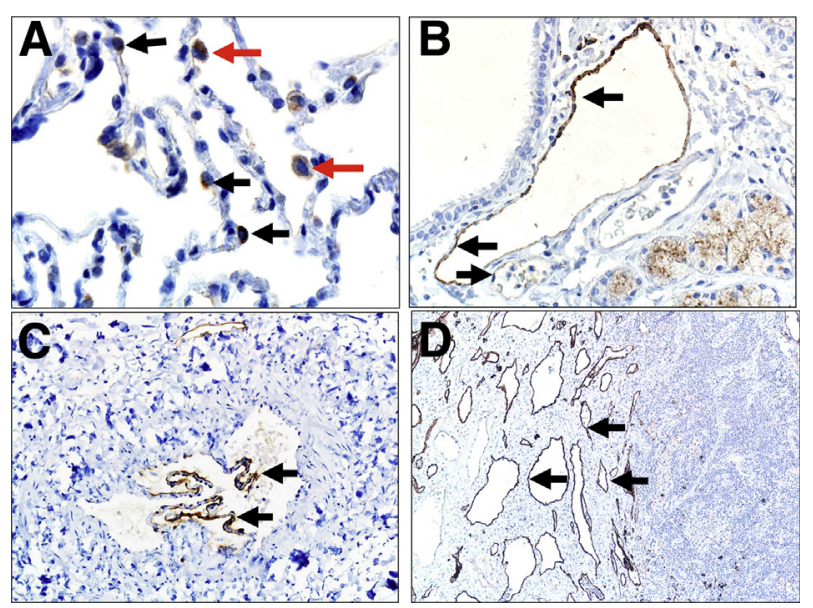

Figure 3 Dipeptidyl peptidase 4 immunostaining in lung. A: Immunostaining is detected in alveolar macrophages (red arrows) and in type II cells (black arrows). B-D: Vascular lining cells have multifocal immunostaining (arrows, B and D). C: A pulmonary vein with preferential immunostaining on vessel valves. D: Pulmonary lymph node with abundant immunostaining of the vascular cells in the medullary sinus (arrows). Original magnifications: $\times 600($ A) $; \times 400$ (B); $\times 200$ (C); $\times 100$ (D). 


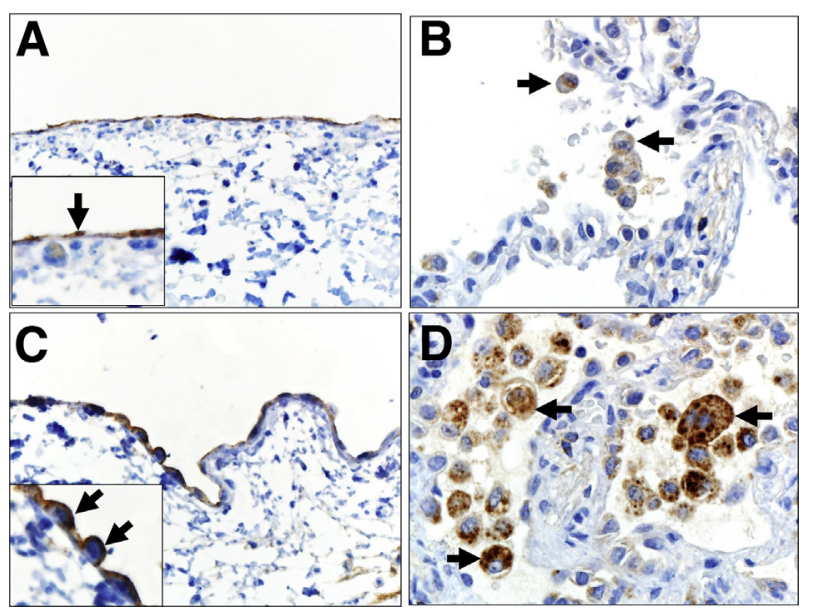

Figure 4 Differential dipeptidyl peptidase 4 (DPP4) immunostaining in relatively healthy (top) and remodeled (bottom) regions of the same cystic fibrosis lung. A and C: DPP4 is detected in the visceral pleura (arrow, inset, A) and has more intense staining in remodeled areas with plump reactive mesothelial cells (arrows, inset, C). B and D: Weak to moderate immunostaining is common in alveolar macrophages (arrows, B) in nominally affected lung. However, in areas of remodeling, activated alveolar macrophages (macrophages with larger, foamier cytoplasm and sometimes multinucleate cells) have more robust immunostaining (arrows, D). Original magnification: $\times 600$ (A-D); $\times 1500$ (A and C, insets).

\section{Influence of Tissue Remodeling on Heterogeneous DPP4 Expression in Chronic Disease Lungs}

Mesothelial lining cells of the visceral pleura were often immunostained except in sections of lung with apparent drying/sloughing artifacts that occurred during tissue preparation (Figure 4A). In areas of remodeling, hypertrophy of mesothelial cells often corresponded with increased DPP4 immunostaining compared with unreactive pleura in the same lung (Figure 4, A and C). Alveolar macrophages often had similarly weak to moderate immunostaining in lung (Figure 4B). However, in the same lung, DPP4 immunostaining was more prominent in activated alveolar macrophages near sites of disease (eg, remodeling) (Figure 4, C and D), and this change was corroborated by semiquantitative scoring (Figure 5).

We then compared DPP4 scoring between group 1 (healthy) and group 2 (chronic disease) to determine whether chronic lung disease affected DPP4 expression (Table 2). Scoring of DPP4 immunostaining in type I and type II (Figure 6, A and B) cells was significantly increased in group 2 lungs (Table 2). Alveolar macrophages also had a similar significant increase in staining for group 2, but neutrophils in both groups consistently lacked DPP4 (Figure 6C). In addition, we observed that groups 1 and 2 had differences in mean age (Table 2), which could possibly contribute to the increased DPP4 scores for type I and type II cells. To address this, we further examined the significant parameters in Table 2 to determine whether there were correlations in the scores with progressive age (Table 3). Although there were no significant correlations between the scores of type I cells and increased age, type II cells had a negative correlation in group $1(r=-0.4887, P=0.0001)$ but lacked a significant correlation when groups 1 and 2 were combined (Table 3). These findings suggest that increased DPP4 scores are not age related but most likely responses to chronic lung disease. An additional question of interest is whether female or male sex contributed to the changes in DPPP4 expression. We detected no significant sex-specific changes in DPP4 expression in alveolar type II cells or alveolar macrophages (Figure 6, D and E).

\section{Discussion}

We evaluated DPP4 expression in the respiratory tract to better understand its association with potential pathogenesis and clinical disease in MERS-CoV infection. It is known that patients with MERS develop severe respiratory disease and that ground-glass changes, edema, and pleural effusions on chest computed tomography typify the lung lesions. However, more detailed descriptions of MERS-CoV lung disease remain elusive because of the absence of autopsy cases for diagnostic evaluation. Our results provide the first comprehensive localization of the MERS-CoV receptor DPP4 in human lung tissues.

Only a few scattered cells on surface epithelia expressed DPP4 in the nasal cavity and conducting airways. Our finding of nominal DPP4 expression in the conducting airways is consistent with a report by van der Velden et al, ${ }^{27}$ who investigated DPP4 expression in human bronchus from healthy individuals and asthmatic patients and noted no localization in surface epithelia but robust expression in submucosal gland epithelia. We detected DPP4 expression on cells within the lung parenchyma (eg, type I and II cells) and interstitium (endothelial cells) and on leukocytes (macrophages, mononuclear lymphoid cells). This finding might suggest that MERS-CoV exposure to airway epithelia

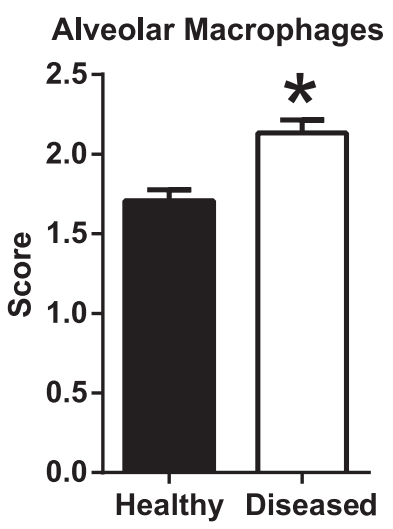

Figure 5 Dipeptidyl peptidase 4 (DPP4) immunostaining increases in activated alveolar macrophages near sites of disease (eg, remodeling). A semiquantitative scoring was used to compare group 1 (healthy) and group 2 (diseased) tissues. Data are expressed as means \pm SD. ${ }^{*} P<0.05$, paired t-test. 

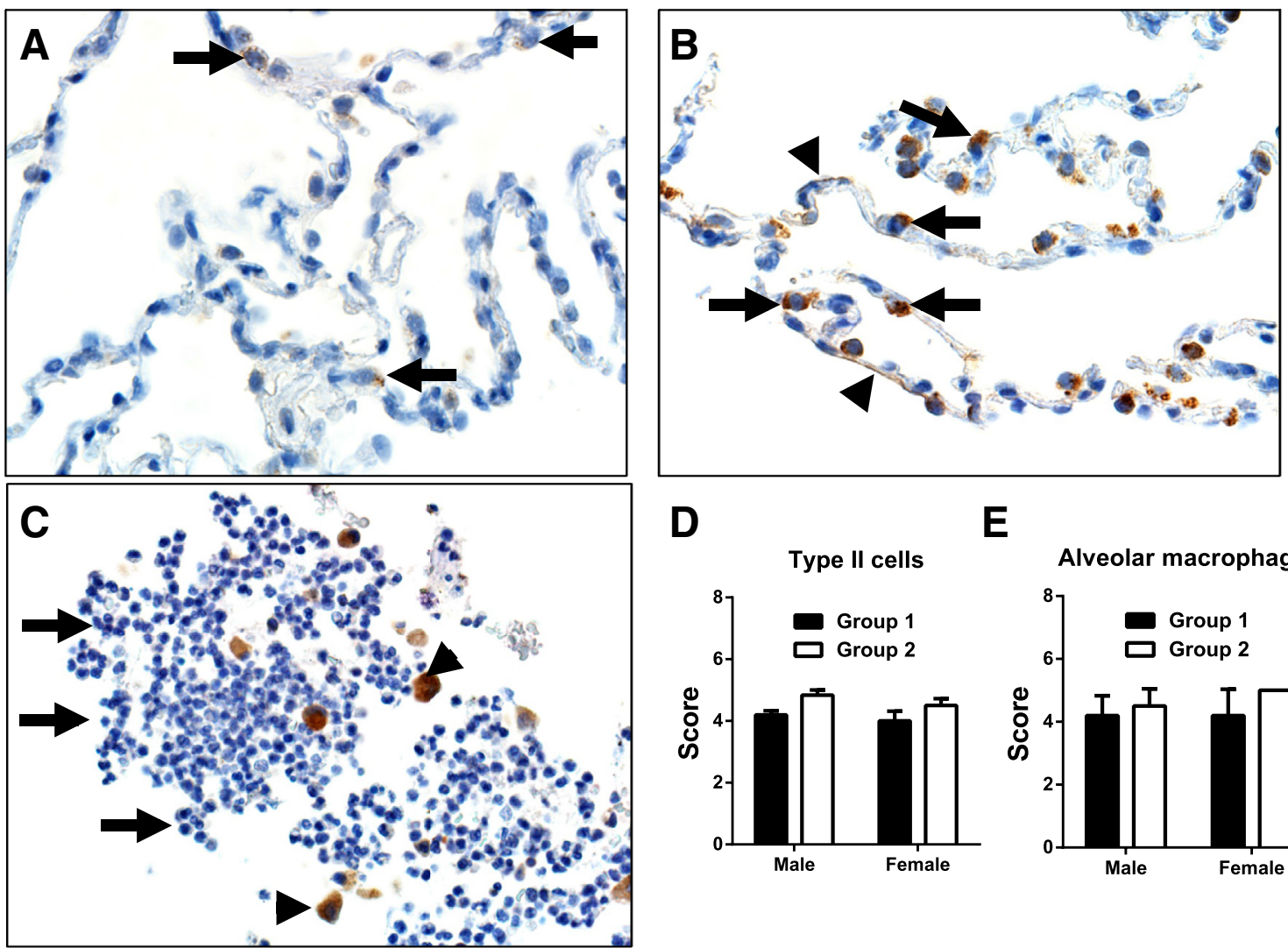

D

$\mathbf{E}$
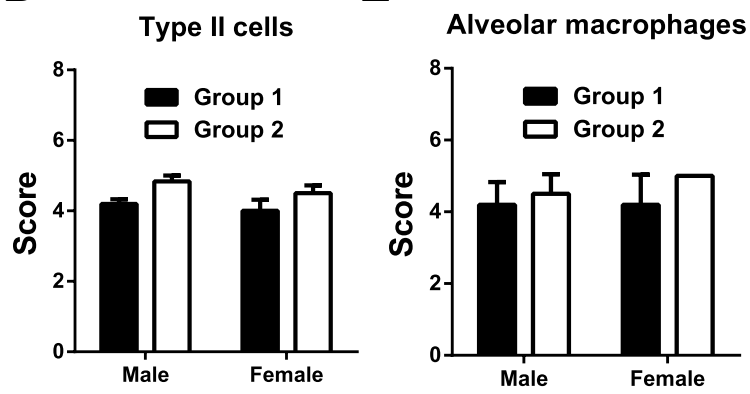

Figure 6 Alveoli of a control (A) and chronic obstructive pulmonary disease (COPD) lung (B and C). A: Dipeptidyl peptidase 4 (DPP4) immunostaining is detected in scattered alveolar type II cells (arrows) in control lungs. B: DPP4 immunostaining increases in intensity in type II cells (arrows) and also in type I cells along septal walls (arrowhead). C: Inflammation in a COPD lung airway. Note the immunostaining in macrophages (arrowheads) but absence of immunostaining in neutrophils (arrows). D and E: Assessment of sex differences in DPP4 expression in healthy (group 1) and diseased (group 2) tissues. No significant sex-related differences in DPP4 expression are found in alveolar type II cells or alveolar macrophages. Data are expressed as means \pm SD (D and E). Original magnification: $\times 600(\mathbf{A}$ and $\mathbf{B}) ; \times 400(\mathbf{C})$.

could provide only a nominal or preliminary conduit for infection but is not a primary site for infection. This concept is consistent with the lack of evidence for airway centric disease in humans and animal models ${ }^{2-4,29,30}$ and may explain the poor transmissibility of MERS-CoV. In contrast, the submucosal glands exhibited robust DPP4 expression in serous epithelial cells and submucosal gland lumens, likely representing soluble DPP4 in secretions. Soluble DPP4 is present in bronchoalveolar lavage fluid, and these levels are regulated independent of serum levels with the extracellular domain cleaved by sheddases, such as matrix metalloproteinase (MMP) 1, MMP-2, and MMP-14. ${ }^{25,31}$ Soluble DPP4 is also detectable in pleural fluid. ${ }^{32}$ In some inflammatory lung conditions, such as smoking, bronchoalveolar lavage levels of soluble DPP4 are reduced, ${ }^{33}$ whereas in other settings, such as asthma, it is unchanged or increased. ${ }^{33,34}$ Submucosal gland secretions normally bathe the airway surface, thus soluble DPP4 from submucosal glands and surface epithelia may bind to the MERS-CoV spike (S) protein. This has been speculated to competitively inhibit virus binding as reported in vitro. ${ }^{22}$ In contrast to the conducting airways, the lung parenchyma and interstitium were relatively rich in cellular sources of DPP4 protein. MERS-CoV infection of these pulmonary cell types would likely contribute to and be consistent with the reported parenchymal lesions observed on lung imaging, such as diffuse alveolar damage. ${ }^{1,3}$

We hypothesized that disease states might modify DPP4 expression. Of interest, DPP4 expression in cells (eg, mesothelium, macrophages) was increased at sites of heterogeneous remodeling compared with healthy sites in the same lung. This finding, along with significant enhanced DPP4 expression scores in type I and type II cells (Tables 2 and 3), suggests that chronic lung disease may enhance DPP4 expression and perhaps make such individuals more susceptible to MERS-CoV infection. Schmiedl et $\mathrm{al}^{34}$ reported an increase in DPP4 tissue staining and activity in a rat model of asthma, indicating that some inflammatory conditions may increase the abundance of MERS-CoV receptor in the airways. It has been reported that patients with MERS and comorbidities, including smoking and COPD, have worse outcomes, suggesting such conditions predispose individuals to an increased susceptibility to MERS$\mathrm{CoV}$ infection or disease progression..$^{2-4,7}$ In addition, it 
is interesting to consider how DPP4 expression on immune cells and vascular endothelia might contribute to MERS$\mathrm{CoV}-$ related disease. Both macrophages and plasmacytoid dendritic cells express DPP4 and are susceptible to MERS$\mathrm{CoV}$ entry. Monocyte-derived macrophages support productive MERS-CoV infection, ${ }^{35,36}$ whereas plasmacytoid dendritic cells support virus entry and release cytokines and interferon in response to entry but do not allow the virus to complete its replication cycle. ${ }^{37} \mathrm{Chu}$ et $\mathrm{al}^{38}$ reported that human $\mathrm{T}$ lymphocytes from the peripheral blood and from lymphoid organs can be infected by MERS-CoV. Of interest, MERS-CoV infection of T lymphocytes activated both the extrinsic and intrinsic apoptosis pathways. ${ }^{38,39}$ In addition to alveolar macrophages and mononuclear cells, we found significant DPP4 immunostaining of endothelia of lymphatics and other vasculature. If these cell types or structures become infected, it is possible that this could contribute to MERS disease pathogenesis by facilitating spread to other organs.

The catalytic domain of DPP4 functions to cleave X-proline dipeptides from the N-terminus of polypeptides. ${ }^{24}$ Cellassociated and soluble DPP4 can regulate the functional activity of bioactive peptides, including neuropeptides, vasoactive peptides, cytokines, and chemokines, by removing N-terminal amino acids. ${ }^{40}$ The present study and other published results indicate that DPP4 could modify peptide function at many sites, including airway and alveolar epithelia, bronchoalveolar lavage, endothelia ${ }^{41}$ (including lymphatics ${ }^{42}$ ), immune cells, and mesothelia. ${ }^{32,43}$ Some examples of known DPP4 substrates include several chemokines, such as SDF-1 $\alpha$ and SDF-1 $\beta$, CXCL2, CXCL6, CXCL9, CXCL10, CXCL11, CXCL12, and CCL22. The catalytic action of DPP4 on substrate chemokines usually reduces the ligand's agonist properties. For example, DPP4-mediated cleavage of CXCL10 yields a dominant negative antagonist peptide product. ${ }^{44}$ It is currently not known whether severe infections such as MERS alter the abundance or function of DPP4 in the respiratory tract, but DPP4 could possibly influence the kinetics of inflammation entering the lung. It addition, there is recent evidence that DPP4 itself may act as a proinflammatory signaling molecule. ${ }^{45,46}$

Chan et $\mathrm{al}^{41}$ found that MERS-CoV productively replicated in human bronchial and lung tissue grown in ex vivo organ cultures. They reported that the virus infected nonciliated bronchial epithelium, bronchiolar epithelial cells, alveolar epithelial cells, and endothelial cells. ${ }^{41}$ Hocke et $\mathrm{al}^{47}$ also used ex vivo organ cultures of human lung to study MERS-CoV cell tropism. They observed that MERS$\mathrm{CoV}$ infected most cell types in the alveolar compartment and detected morphologic correlates of severe lung injury. Although ex vivo models are useful, it is possible that culture conditions may alter native DPP4 expression or other factors that influence cell susceptibility to MERS-CoV infection. Several groups have reported that infection of airway epithelial cell lines with MERS-CoV elicits a range of transcriptional and protein responses, including antagonism of interferon responses, induction of STAT3 pathway genes, and differential expression of cytokines and chemokines. ${ }^{25,48-50}$ It is not currently known how infection of endothelia, mesothelia, or immune cell types with MERS$\mathrm{CoV}$ might influence disease outcomes.

This study has advantages and limitations. One advantage is that we used cell cultures and known positive tissue to optimize and validate the technique to maximize specificity and minimize nonspecific background that can easily confound localization studies. Another advantage is that we immunostained tissue from a range of healthy and diseased individuals to comprehensively investigate DPP4 distribution across all lung cell types. Other studies have used DPP4 activity-based localization techniques ${ }^{51}$ in addition to immunolocalization $^{25,27}$ or in vitro culture of primary cells and cell lines. ${ }^{22,52,53}$ Of note, we found that tissues from patients with COPD and CF exhibited areas of enhanced DPP4 immunostaining in airway epithelia, type II epithelia, pleural mesothelia, and alveolar macrophages. A disadvantage of this study is that the tissues from disease states tended to be from older individuals, but this age difference did not appear to directly influence the study findings. Another limitation of this study is the relatively small number of cases in the COPD and CF groups. Even so, we identified significant trends from this cohort. Furthermore, small sample sizes of nasal tissue biopsies constrained the tissue area for examination compared with other tissues, and this small sampling could explain the absence of DPP4 staining in nasal surface epithelium compared with sparse staining in airway surface epithelium. We acknowledge that very little DPP4 expression may be required to confer susceptibility to MERS-CoV infection, and this could be below the level of detection with the optimized IHC technique. We also speculate that although the expression of DPP4 alone is sufficient to confer susceptibility to MERS-CoV infection in resistant cells, ${ }^{22}$ it is possible that there may be currently unknown cell-type specific co-factors, such as host proteases ${ }^{54}$ that influence disease that we could not evaluate. In summary, the evidence of more prominent localization of DPP4 in parenchymal tissue may help explain why MERS is characterized by lower respiratory tract disease.

\section{Acknowledgments}

We thank Tom Gallagher and Stanley Perlman for careful review of the manuscript.

\section{References}

1. Zaki AM, van Boheemen S, Bestebroer TM, Osterhaus AD, Fouchier RA: Isolation of a novel coronavirus from a man with pneumonia in Saudi Arabia. N Engl J Med 2012, 367:1814-1820

2. Arabi YM, Arifi AA, Balkhy HH, Najm H, Aldawood AS, Ghabashi A, Hawa H, Alothman A, Khaldi A, Al Raiy B: Clinical course and outcomes of critically ill patients with Middle East respiratory syndrome coronavirus infection. Ann Intern Med 2014, 160: 389-397 
3. Kapoor M, Pringle K, Kumar A, Dearth S, Liu L, Lovchik J, Perez O, Pontones P, Richards S, Yeadon-Fagbohun J, Breakwell L, Chea N, Cohen NJ, Schneider E, Erdman D, Haynes L, Pallansch M, Tao Y, Tong S, Gerber S, Swerdlow D, Feikin DR: Clinical and laboratory findings of the first imported case of Middle East respiratory syndrome coronavirus to the United States. Clin Infect Dis 2014, 59: $1511-1518$

4. Saad M, Omrani AS, Baig K, Bahloul A, Elzein F, Matin MA, Selim MA, Al Mutairi M, Al Nakhli D, Al Aidaroos AY, Al Sherbeeni N, Al-Khashan HI, Memish ZA, Albarrak AM: Clinical aspects and outcomes of 70 patients with Middle East respiratory syndrome coronavirus infection: a single-center experience in Saudi Arabia. Int J Infect Dis 2014, 29:301-306

5. Assiri A, McGeer A, Perl TM, Price CS, Al Rabeeah AA, Cummings DA, Alabdullatif ZN, Assad M, Almulhim A, Makhdoom H, Madani H, Alhakeem R, Al-Tawfiq JA, Cotten M, Watson SJ, Kellam P, Zumla AI, Memish ZA; Team KM-CI: Hospital outbreak of Middle East respiratory syndrome coronavirus. N Engl J Med 2013, 369:407-416

6. Hui DS, Perlman S, Zumla A: Spread of MERS to South Korea and China. Lancet Respir Med 2015, 3:509-510

7. Al-Hameed F, Wahla AS, Siddiqui S, Ghabashi A, Al-Shomrani M, Al-Thaqafi A, Tashkandi Y: Characteristics and outcomes of Middle East respiratory syndrome coronavirus patients admitted to an intensive care unit in Jeddah, Saudi Arabia. J Intensive Care Med 2015, [Epub ahead of print]

8. Ajlan AM, Ahyad RA, Jamjoom LG, Alharthy A, Madani TA: Middle East respiratory syndrome coronavirus (MERS-CoV) infection: chest CT findings. AJR Am J Roentgenol 2014, 203:782-787

9. Arabi YM, Harthi A, Hussein J, Bouchama A, Johani S, Hajeer AH, Saeed BT, Wahbi A, Saedy A, AlDabbagh T, Okaili R, Sadat M, Balkhy H: Severe neurologic syndrome associated with Middle East respiratory syndrome corona virus (MERS-CoV). Infection 2015, 43: 495-501

10. Yusof MF, Eltahir YM, Serhan WS, Hashem FM, Elsayed EA, Marzoug BA, Abdelazim AS, Bensalah OK, Al Muhairi SS: Prevalence of Middle East respiratory syndrome coronavirus (MERS-CoV) in dromedary camels in Abu Dhabi Emirate, United Arab Emirates. Virus Genes 2015, 50:509-513

11. Chan RW, Hemida MG, Kayali G, Chu DK, Poon LL, Alnaeem A, Ali MA, Tao KP, Ng HY, Chan MC, Guan Y, Nicholls JM, Peiris JS: Tropism and replication of Middle East respiratory syndrome coronavirus from dromedary camels in the human respiratory tract: an invitro and ex-vivo study. Lancet Respir Med 2014, 2:813-822

12. Wernery U, Corman VM, Wong EY, Tsang AK, Muth D, Lau SK, Khazanehdari K, Zirkel F, Ali M, Nagy P, Juhasz J, Wernery R, Joseph S, Syriac G, Elizabeth SK, Patteril NA, Woo PC, Drosten C: Acute middle East respiratory syndrome coronavirus infection in livestock dromedaries, Dubai, 2014. Emerg Infect Dis 2015, 21:1019-1022

13. Azhar EI, El-Kafrawy SA, Farraj SA, Hassan AM, Al-Saeed MS, Hashem AM, Madani TA: Evidence for camel-to-human transmission of MERS coronavirus. N Engl J Med 2014, 370: 2499-2505

14. Yu IT, Li Y, Wong TW, Tam W, Chan AT, Lee JH, Leung DY, Ho T: Evidence of airborne transmission of the severe acute respiratory syndrome virus. N Engl J Med 2004, 350:1731-1739

15. Wang Sh X, Li YM, Sun BC, Zhang SW, Zhao WH, Wei MT, Chen KX, Zhao XL, Zhang ZL, Krahn M, Cheung AC, Wang PP: The SARS outbreak in a general hospital in Tianjin, China - the case of super-spreader. Epidemiol Infect 2006, 134:786-791

16. Perlman S, McCray PB Jr: Person-to-person spread of the MERS coronavirus-an evolving picture. N Engl J Med 2013, 369:466-467

17. Breban R, Riou J, Fontanet A: Interhuman transmissibility of Middle East respiratory syndrome coronavirus: estimation of pandemic risk. Lancet 2013, 382:694-699

18. Memish ZA, Assiri AM, Al-Tawfiq JA: Middle East respiratory syndrome coronavirus (MERS-CoV) viral shedding in the respiratory tract: an observational analysis with infection control implications. Int J Infect Dis 2014, 29:307-308

19. Memish ZA, Zumla AI, Al-Hakeem RF, Al-Rabeeah AA, Stephens GM: Family cluster of Middle East respiratory syndrome coronavirus infections. N Engl J Med 2013, 368:2487-2494

20. Memish ZA, Al-Tawfiq JA, Assiri A, AlRabiah FA, Al Hajjar S, Albarrak A, Flemban H, Alhakeem RF, Makhdoom HQ, Alsubaie S, Al-Rabeeah AA: Middle East respiratory syndrome coronavirus disease in children. Pediatr Infect Dis J 2014, 33:904-906

21. Madani TA: Case definition and management of patients with MERS coronavirus in Saudi Arabia. Lancet Infect Dis 2014, 14:911-913

22. Raj VS, Mou H, Smits SL, Dekkers DH, Muller MA, Dijkman R, Muth D, Demmers JA, Zaki A, Fouchier RA, Thiel V, Drosten C, Rottier PJ, Osterhaus AD, Bosch BJ, Haagmans BL: Dipeptidyl peptidase 4 is a functional receptor for the emerging human coronavirus-EMC. Nature 2013, 495:251-254

23. Lu G, Hu Y, Wang Q, Qi J, Gao F, Li Y, Zhang Y, Zhang W, Yuan Y, Bao J, Zhang B, Shi Y, Yan J, Gao GF: Molecular basis of binding between novel human coronavirus MERS-CoV and its receptor CD26. Nature 2013, 500:227-231

24. Lambeir AM, Durinx C, Scharpe S, De Meester I: Dipeptidyl-peptidase IV from bench to bedside: an update on structural properties, functions, and clinical aspects of the enzyme DPP IV. Crit Rev Clin Lab Sci 2003, 40:209-294

25. Juillerat-Jeanneret L, Aubert JD, Leuenberger P: Peptidases in human bronchoalveolar lining fluid, macrophages, and epithelial cells: dipeptidyl (amino)peptidase IV, aminopeptidase $\mathrm{N}$, and dipeptidyl (carboxy)peptidase (angiotensin-converting enzyme). J Lab Clin Med 1997, 130:603-614

26. Mentzel S, Dijkman HB, Van Son JP, Koene RA, Assmann KJ: Organ distribution of aminopeptidase A and dipeptidyl peptidase IV in normal mice. J Histochem Cytochem 1996, 44:445-461

27. van der Velden VH, Wierenga-Wolf AF, Adriaansen-Soeting PW, Overbeek SE, Moller GM, Hoogsteden HC, Versnel MA: Expression of aminopeptidase $\mathrm{N}$ and dipeptidyl peptidase IV in the healthy and asthmatic bronchus. Clin Exp Allergy 1998, 28:110-120

28. Gibson-Corley KN, Olivier AK, Meyerholz DK: Principles for valid histopathologic scoring in research. Vet Pathol 2013, 50:1007-1015

29. Zhao J, Li K, Wohlford-Lenane C, Agnihothram SS, Fett C, Zhao J, Gale MJ Jr, Baric RS, Enjuanes L, Gallagher T, McCray PB Jr, Perlman S: Rapid generation of a mouse model for Middle East respiratory syndrome. Proc Natl Acad Sci U S A 2014, 111: 4970-4975

30. Agrawal AS, Garron T, Tao X, Peng BH, Wakamiya M, Chan TS, Couch RB, Tseng CT: Generation of transgenic mouse model of Middle East respiratory syndrome coronavirus infection and disease. J Virol 2015, 89:3659-3670

31. Rohrborn D, Eckel J, Sell H: Shedding of dipeptidyl peptidase 4 is mediated by metalloproteases and up-regulated by hypoxia in human adipocytes and smooth muscle cells. FEBS Lett 2014, 588: 3870-3877

32. Sanchez-Otero N, Rodriguez-Berrocal FJ, de la Cadena MP, BotanaRial MI, Cordero OJ: Evaluation of pleural effusion sCD26 and DPPIV as diagnostic biomarkers in lung disease. Sci Rep 2014, 4:3999

33. van der Velden VH, Naber BA, Van Hal PT, Overbeek SE, Hoogsteden HC, Versnel MA: Peptidase activities in serum and bronchoalveolar lavage fluid from allergic asthmatics-comparison with healthy non-smokers and smokers and effects of inhaled glucocorticoids. Clin Exp Allergy 1999, 29:813-823

34. Schmiedl A, Krainski J, Schwichtenhovel F, Schade J, Klemann C, Raber KA, Zscheppang K, Beekmann T, Acevedo C, Glaab T, Wedekind D, Pabst R, von Horsten S, Stephan M: Reduced airway inflammation in CD26/DPP4-deficient F344 rats is associated with altered recruitment patterns of regulatory $\mathrm{T}$ cells and expression of pulmonary surfactant proteins. Clin Exp Allergy 2010, 40:1794-1808

35. Zhou J, Chu H, Li C, Wong BH, Cheng ZS, Poon VK, Sun T, Lau CC, Wong KK, Chan JY, Chan JF, To KK, Chan KH, Zheng BJ, 
Yuen KY: Active replication of Middle East respiratory syndrome coronavirus and aberrant induction of inflammatory cytokines and chemokines in human macrophages: implications for pathogenesis. J Infect Dis 2014, 209:1331-1342

36. Chu H, Zhou J, Wong BH, Li C, Cheng ZS, Lin X, Poon VK, Sun T, Lau CC, Chan JF, To KK, Chan KH, Lu L, Zheng BJ, Yuen KY: Productive replication of Middle East respiratory syndrome coronavirus in monocyte-derived dendritic cells modulates innate immune response. Virology 2014, 454-455:197-205

37. Scheuplein VA, Seifried J, Malczyk AH, Miller L, Hocker L, Vergara-Alert J, Dolnik O, Zielecki F, Becker B, Spreitzer I, Konig R, Becker S, Waibler Z, Muhlebach MD: High secretion of interferons by human plasmacytoid dendritic cells upon recognition of Middle East respiratory syndrome coronavirus. J Virol 2015, 89: 3859-3869

38. Chu H, Zhou J, Wong BH, Li C, Chan JF, Cheng ZS, Yang D, Wang D, Lee AC, Li C, Yeung ML, Cai JP, Chan IH, Ho WK, To KK, Zheng BJ, Yao Y, Qin C, Yuen KY: Middle East respiratory syndrome coronavirus efficiently infects human primary $\mathrm{T}$ lymphocytes and activates both the extrinsic and intrinsic apoptosis pathways. J Infect Dis 2015, [Epub ahead of print]

39. Ying $\mathrm{T}, \mathrm{Li} \mathrm{W}$, Dimitrov DS: Discovery of $\mathrm{T}$ cell infection and apoptosis by MERS Coronavirus. J Infect Dis 2015, [Epub ahead of print]

40. de Meester I, Lambeir AM, Proost P, Scharpe S: Dipeptidyl peptidase IV substrates: an update on in vitro peptide hydrolysis by human DPPIV. Adv Exp Med Biol 2003, 524:3-17

41. Chan RW, Chan MC, Agnihothram S, Chan LL, Kuok DI, Fong JH, Guan Y, Poon LL, Baric RS, Nicholls JM, Peiris JS: Tropism of and innate immune responses to the novel human betacoronavirus lineage C virus in human ex vivo respiratory organ cultures. J Virol 2013, 87: 6604-6614

42. Shin JW, Jurisic G, Detmar M: Lymphatic-specific expression of dipeptidyl peptidase IV and its dual role in lymphatic endothelial function. Exp Cell Res 2008, 314:3048-3056

43. Kajiyama H, Kikkawa F, Maeda O, Suzuki T, Ino K, Mizutani S: Increased expression of dipeptidyl peptidase IV in human mesothelial cells by malignant ascites from ovarian carcinoma patients. Oncology 2002, 63:158-165

44. Casrouge A, Decalf J, Ahloulay M, Lababidi C, Mansour H, ValletPichard A, Mallet V, Mottez E, Mapes J, Fontanet A, Pol S, Albert ML: Evidence for an antagonist form of the chemokine CXCL10 in patients chronically infected with HCV. J Clin Invest 2011, 121:308-317

45. Wronkowitz N, Gorgens SW, Romacho T, Villalobos LA, SanchezFerrer CF, Peiro C, Sell H, Eckel J: Soluble DPP4 induces inflammation and proliferation of human smooth muscle cells via protease-activated receptor 2. Biochim Biophys Acta 2014, 1842: $1613-1621$

46. Ikeda T, Kumagai E, Iwata S, Yamakawa A: Soluble CD26/dipeptidyl peptidase IV enhances the transcription of IL- 6 and TNFalpha in THP-1 cells and monocytes. PLoS One 2013, 8:e66520

47. Hocke AC, Becher A, Knepper J, Peter A, Holland G, Tonnies M, Bauer TT, Schneider P, Neudecker J, Muth D, Wendtner CM, Ruckert JC, Drosten C, Gruber AD, Laue M, Suttorp N, Hippenstiel S, Wolff T: Emerging human middle East respiratory syndrome coronavirus causes widespread infection and alveolar damage in human lungs. Am J Respir Crit Care Med 2013, 188:882-886

48. Josset L, Menachery VD, Gralinski LE, Agnihothram S, Sova P, Carter VS, Yount BL, Graham RL, Baric RS, Katze MG: Cell host response to infection with novel human coronavirus EMC predicts potential antivirals and important differences with SARS coronavirus. MBio 2013, 4:e0165-13

49. Selinger C, Tisoncik-Go J, Menachery VD, Agnihothram S, Law GL, Chang J, Kelly SM, Sova P, Baric RS, Katze MG: Cytokine systems approach demonstrates differences in innate and pro-inflammatory host responses between genetically distinct MERS-CoV isolates. BMC Genomics 2014, 15:1161

50. Menachery VD, Eisfeld AJ, Schafer A, Josset L, Sims AC, Proll S, Fan S, Li C, Neumann G, Tilton SC, Chang J, Gralinski LE, Long C, Green R, Williams CM, Weiss J, Matzke MM, Webb-Robertson BJ, Schepmoes AA, Shukla AK, Metz TO, Smith RD, Waters KM, Katze MG, Kawaoka Y, Baric RS: Pathogenic influenza viruses and coronaviruses utilize similar and contrasting approaches to control interferon-stimulated gene responses. MBio 2014, 5:e1174-14

51. Jornot L, Grouzmann E, Lacroix JS, Rochat T: BDNF and DPP-IV in polyps and middle turbinates epithelial cells. Rhinology 2007, 45: 129-133

52. Chan JF, Chan KH, Choi GK, To KK, Tse H, Cai JP, Yeung ML, Cheng VC, Chen H, Che XY, Lau SK, Woo PC, Yuen KY: Differential cell line susceptibility to the emerging novel human betacoronavirus 2c EMC/2012: implications for disease pathogenesis and clinical manifestation. J Infect Dis 2013, 207: $1743-1752$

53. Tao X, Hill TE, Morimoto C, Peters CJ, Ksiazek TG, Tseng CT: Bilateral entry and release of Middle East respiratory syndrome coronavirus induces profound apoptosis of human bronchial epithelial cells. J Virol 2013, 87:9953-9958

54. Zhou Y, Vedantham P, Lu K, Agudelo J, Carrion R Jr, Nunneley JW, Barnard D, Pohlmann S, McKerrow JH, Renslo AR, Simmons G: Protease inhibitors targeting coronavirus and filovirus entry. Antiviral Res 2015, 116:76-84 